\title{
Bancassurance in a digital era
}

\author{
Elda MARZAI (ABLIZ) \\ The Bucharest University of Economic Studies, Bucharest, Romania \\ elda.abliz@yahoo.com
}

\begin{abstract}
The implementation of bancassurance activity in the banking field contributes to the strengthening of the competitive environment, the development of new products in insurance and the higher satisfaction of the consumer's needs. The strategic priorities of banks are to increase business protection by adding new products to their portfolios, according customer's needs. The distribution of insurance in the bancassurance system is a future solution and will continue to develop on the Romanian market as well. Bancassurance is the main distribution channel in many countries, accounting for more than 50\% of life insurance products (eg France, Italy, Spain, Austria), in Portugal the share goes up to $80 \%$ and in Romania is around 30\%. Among the aspects needed to develop this service, bank representatives propose both the diversification of types of insurance sold through banks, as well as the growth of consumer financial education development and digitalization. This paper aims to highlight different perspectives to relaunch bancassurance activity according to changes from customer behavior and the identification of factors which contributing to the sustainability of bancassurance in digital environment. In addition, will be presented a comparison of the internet penetration rate in the world, the categories of clients using online banking services.
\end{abstract}

Keyword : bancassurance, insurance, digitalization, digitization, e-commerce.

\section{Introduction}

The development of financial markets and the increasing importance of banks in the economic and financial environment led to specialization and diversification of banking services and products. Thus, banks also accessed capital markets in competition with securities, insurance, mutual funds and pension funds.

The competitive pressure from other financial market segments (such as insurance and capital markets) has prompted banks to initiate and develop new services such as Bancassurance.

The banking services sector requires a specific approach to the establishment of the portfolio of products and services that will be offered by the bank in order to adapt to the needs of the clients. Present research, demonstrates that the behavior of customers is changing from traditional to digital, so, banks needs to adapt their products to trends and dynamics that characterizes the global insurance industry.

\section{Literature review}

The impact of involvement by banks in insurance activities has attracted the attention of many researchers ; based upon a cost -benefit analysis, Bergendahl (1995) suggested that the benefits of bancassurance may be attributable to customers, being essential to satisfy their individual needs, to offer low-cost products and treated like "in-house". Singhal and Singh (2010) argued that bancassurance could increase scale economies by utilizing the existing networks of the banks to offer greater ranges of products, also increasing the efficiency and skills of bank employees as they face the new challenges. Amici et al. (2013) investigated the impact by examining strategic alliances and joint ventures between banks 
and insurance companies, Slijkerman et al. (2013) suggested that systemic risk could be lowered through financial conglomeration between banks and insurance companies.

There are some theories that have led to the development and expansion of bancassurance. The most important are: Insurance sales costs are substantially reduced when policies are cross-sold to a bank customer base (Nicholson,1990); Selling insurance products implies that the own customer data base of each bank will be better protected against competition from other banks (OECD,1993,p.47); Bank and insurance services are joint products and cannot be obtained separately. The insurance products have to be standardized, at low costs and have their own advantages (OECD,1992).

According to Pantano and Timmermans (2014), the implementation of smart technologies in retail needs modifications in both selling activities and businesses processes. The authors highlight that from an organisational point of view, smart technologies require an effort for recognizing, selecting and presenting the finest technology, while enhancing the way to generate, obtain, manage and transfer knowledge from customers to companies and vice versa. At the same time, there is a need for retailers to understand the consumers' demands and their behavioural intentions (Chang et al.,2016) such as customers' perceived value and effort expectancy (Cronin, Brady, \& Hult, 2000; Teo \& Lim, 2001), which is also aided by the introduction of smart technology.

So, the use of technology becomes smart by connecting retailers and clients with the mutual goal of achieving better customer dynamics and customer experience (Ahmadinia, Karim, \& Ofori, 2015). According to the literature, bancassurance implementation in banks' activity can lead to efficiency and profitability of banks, as products are launched to satisfy customer needs.

\section{Bancassurance history}

The emergence of insurance is related to the need to reduce the risks and the security of their coverage. The need for insurance is related to the existence of possible events, which may pose a threat to the integrity of material assets or to people's lives: calamities, accidents, incidents, etc. Faced with these dangers, people's need to protect has led to its solidarity in the process of preventing the effects of events (insurance risks).

The proper insurance, in the simplest, classic way, but also the most commonly encountered in practice, consists in financial protection for losses caused by a wide and varied range of risks.

The insurance is based on a voluntary agreement (contract) concluded between the insurer and the insured, whereby the insurer provides the insured with protection against the risks he has assumed, forcing himself to cover the insured, the value of the damages (ie the sum insured in the case of life insurance) in case of such events, in exchange for the insured's payment of an amount of money, called the "insurance premium".

In order to hedge the risks related to the sale of financial banking products through the Bank, a new concept - Bancassurance was launched.

Bancassurance is an insurance brokerage activity that is complementary to the products of credit institutions and non-banking financial institutions, carried out through the network of these institutions (art. 2 , law no. 32/2000). The specific nature of this activity lies in the fact that insurance intermediation has only an accessory, complementary character. The bancassurance activity is mediating contracting of insurance that accompanies the operations in the field of banking finance referring to various types of credits (for example, 
the life insurance concluded when contracting a mortgage loan).

The bancassurance concept may refer to a relationship between a bank and an insurance company, through which the bank offers its clients the possibility to achieve an insurance product. Bancassurance is a growth model for the financial sector that relies on the proximity of banks and insurance companies to build strong financial pools.

The implementation of bancassurance activity in the banking field contributes to the PICBE | 603 strengthening of the competitive environment, the development of new products in insurance and the higher satisfaction of the consumer's needs.

Customers may, in many instances, view financial services in packages or bundles. It is critical, however, to design the product bundles to satisfy both the bank's and its customers interests. From the bank's perspective, a combination of attractive and slightly less attractive services helps the sale of the latter. From the customer's perspective, the bundle needs to offer particular benefits and in order for this to be successful, bundles need to developed that are targeted towards specific segments.

Definition of the concept of bancassurance has a functional and institutional aspect. The first aspect defines the concept of bancassurance as a set of banking and insurance products. The second concerns the way in which collaboration between banks and insurance companies is organized.

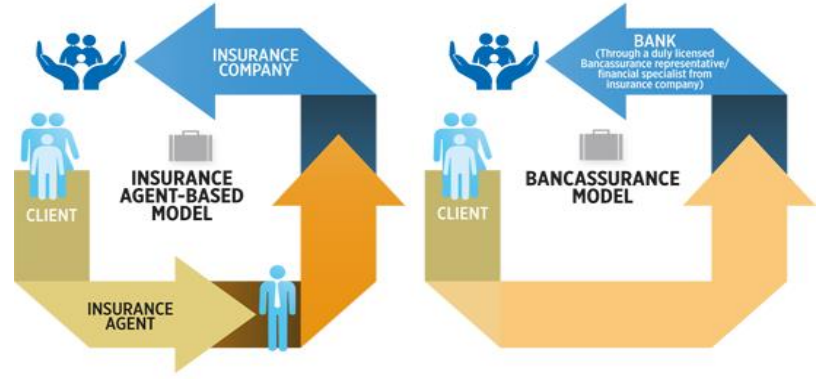

Figure 1. The process of concluding insurance policies through Bancassurance source: BusinessWorld Publishing, http://www.bworldonline.com.

The Bank-Insurer Partnership is win-win category. First of all, Banks are assured by decreasing the risks of bank products sold. Banks will create new integrated insurance products to satisfy customer requirements. By selling insurance, Banks can expand their portfolio of potential clients and obtain additional income sources. The insurance companies also benefit from a partnership with the Banks, for the expansion of the activity, having access to portfolio of retail or company clients, benefit from the bank's infrastructure and services, benefit from a new distribution channel insurance.

In Europe, bancassurance expansion was favored by the EC Directive92 which provided for the formation of the unique market, and legislation allows for alliances between banks and insurance companies.

In this sense, two main trends have been noted. The first trend is manifested at the level of exploitation through acquisitions and mergers. The second tendency is manifested in the form of packages of services designed to cover the financial needs of the clients. The services are provided by networks including independent banks, insurers and brokers. The first model was noted in France and the second one in the Netherlands.

The first bank who launch integrated bancassurance financial services is Credit Mutuel, in order to provide loans to businesses. In Romania, the bancassurance product first appear in 2001, while in France this product first appeared in 1980.

The emergence of bancassurance solutions in Romania is related to retail banking. 
Most consist in insurance attached to a bank loan to protect the risk of non-payment or death of the borrower. This type of insurance often accompanies a mortgage or real estate loan, being contracted for a long time, having a higher value. In Switzerland, bancassurance services have expanded to the small and medium-sized enterprise sector, covering the specific financial needs or specific needs compatible with the bancassurance system.

In a training market, the success of bancassurance is conditioned by the ability of PICBE | 604 selecting the "right" partner for both insurance companies and banks, identifying the segments from which most customers may come.

The two Bancassurance models implemented in Europe are: Integrated Model and Non-Integrated Model. In the Integrated Model (predominantly in Southern Europe), banking and insurance are perfectly integrated, bank branch employees sell insurance products and these are created specifically for the bank's specific needs and customers. In the nonintegrated module (predominantly in Germany and UK), insurance products are sold by specialized insurance agents. The Bank acts as an agent for one or more insurers, based on an agreement, and the integrated Bancassurance model focuses on customer relationship management, offering an intact process and keeping the opportunity in the financial group.

Within the financial packages, bancassurance offers classic banking products and standardized life and non-life insurance products. Life insurance accounts for a significant share, about $1 / 3$ of US life insurance and investment products, and $2 / 3$ of the same product categories in Europe are sold in the bancassurance system. Nowadays, on the European market, bancassurance covers more than $35 \%$ of life insurance sales and is one of the dominant distribution channels in several European countries such as Belgium, France, Italy, Spain and Portugal (Chawla şi Singh, 2008).

The insurance must be a business based on trust and expectations. The clients need to have trust in the person or the institution who sell the insurance. The buyer must be confident that the product is sold at a fair price and that the insurer will remain solvent throughout the insurance period.

Also, banking experience can bring added value and a higher level of counseling and financial education to consumers. Bancassurance must not only be a simple sale of insurance policies, but presupposes in advance the correct, complete information and professional guidance of the client towards a certain product.

\section{Distribution channels}

For many years, much of insurance industry has depended on a large force of highly specialized agents dedicated to selling insurance. This strong interdependece between companies and agents continues today. Nevertheless, pressure in the marketplace are bringing changes to these relationships.

Agents are seeking additional products and services to compete in the world of diversified financial services. If they are to be competitive with other financial services providers, insurance companies must both strengthen the traditional agency distribution system with new product lines, and through new technology, reduce costs associated with the agency system. In general, insurance companies are considered to be able to sell their products in two major ways, either through insurance agents / insurance companies or through insurance intermediaries. The distribution channel is one of the main elements of the marketing mix and is very important for the positioning of products / services on the market. Therefore, the established distribution channels of insurance are considered to be 
represented by their own employees, insurance agents and sub-insurance, insurance brokers and subordinated insurance agents (bancassurance operators).

Insurance agents may be natural or legal persons empowered, on the basis of the authorization of an insurer, to conclude contracts on behalf of the insurer with third parties by proposing their products to potential insured customers. Insurance agents cannot offer competing products to many insurers, forbidden to promote products in the same class on behalf of several insurers. Insurance agents are subject to authorization by the insurer and the latter is responsible for the activity of the insurance agents.

Insurance subagents are employees of insurance agents constituted as legal persons, who may act on behalf of such insurance agents. There is no legal link between insurers and subagents.

Insurance brokers are legal entities that negotiate for their clients, natural or legal persons, insured or potential insured persons, conclude insurance contracts and provide them with assistance before and during the performance of the contracts, or in relation to the management of claims, as the case may be. Insurance brokers act on behalf of policyholders and can therefore work with more active insurers on the market and offer their clients a range of competing products. Insurance brokers are subject to ASF approval and regulatory provisions prevent insurers from participating in their share capital.

Subordinated insurance agents or bancassurance operators are banking institutions or non-banking financial institutions that can only distribute insurance products that are complementary to their financial products. Subordinate insurance agents act based on agency contracts and can do this with different insurers for the same classes of insurance.

Insurance companies can also use other ways to reach out to their final customers, for example through telesales who work in their own or specialized call centers or through the web interfaces available on insurance companies' websites. Even if telemarketing or online sales can be circumscribed to established distribution channels, these sales are sometimes viewed separately, especially because of the novelty feature that characterizes them. Bancassurance - insurance distribution represents a future solution and will continue to develop on the Romanian market as well. Bancassurance is the main channel of distribution in many countries, accounting for more than $50 \%$ of life insurance products (eg France, Italy, Spain, Austria) and in Portugal even more than $80 \%$. 


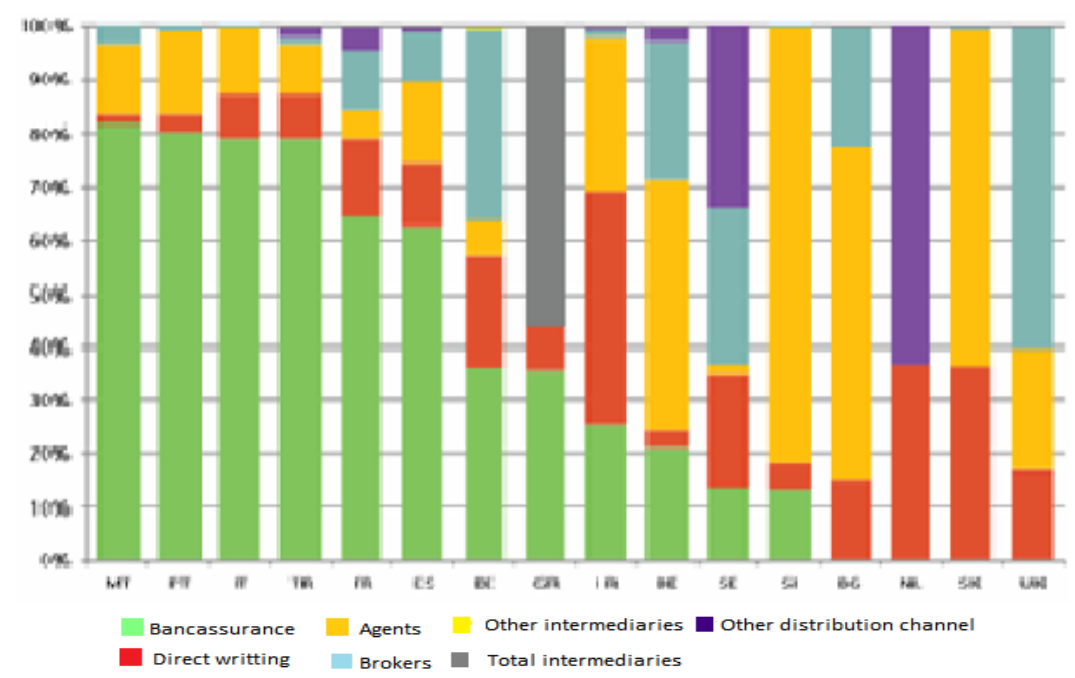

PICBE | 606

Figure 2. Life distribution channels by country (\%of GWP)-2014

Source: European Insurance in figures /online/https://www.insuranceeurope.eu/ sites/ default/ files/ attachments/EuropeanInsurance/KeyFacts/2016.pdf

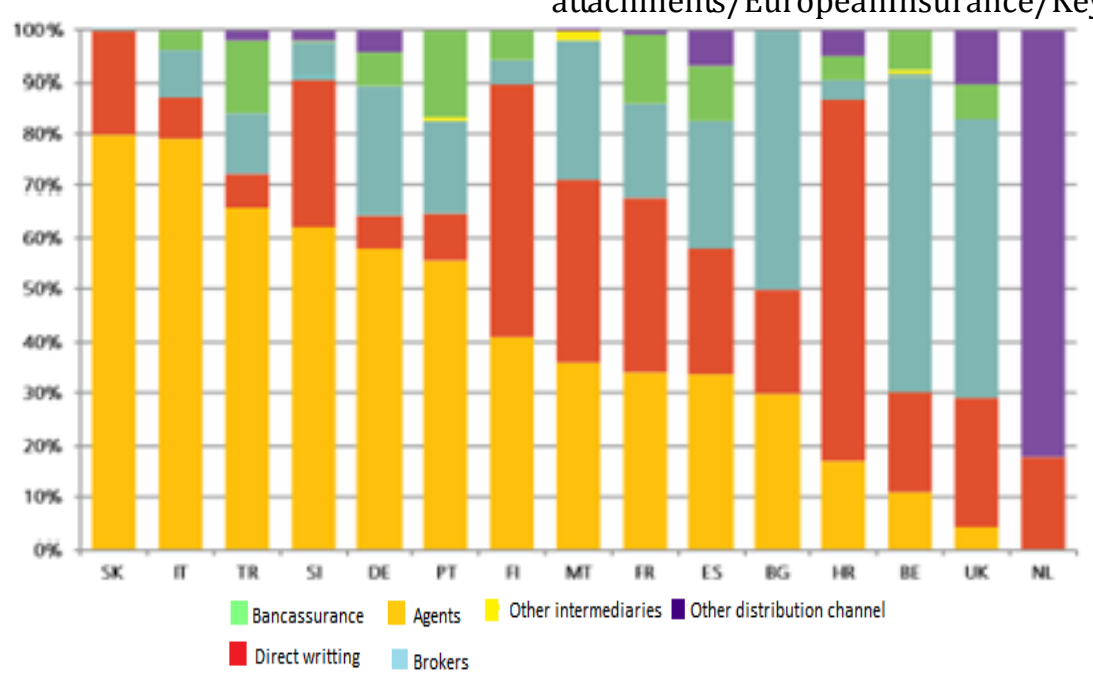

Figure 3. Non-Life distribution channels by country (\%of GWP)-2014

Source: European Insurance in figures /online/https://www.insuranceeurope.eu/ sites/ default/ files/ attachments/EuropeanInsurance/KeyFacts/2016.pdf

The distribution channel - Bancassurance is an engine of rapid growth in the insurance market and, in particular, life insurance. A strong bancassurance strategy can generate significant incomes without capital costs for the bank, with major benefits. Most of the banks have actively engaged client -oriented strategies. Industry players are developing their approach when it comes to understanding the types of customers and offering products adapted to their needs. The importance of customer relationships is essential for developing a competitive edge.

\section{Methodology}

The present research is based on the statistical data, regarding the modification of customer behavior through digitalization, the growing role of e-commerce in Europe and explores if 
together they can have an influence on banking activity - bancassurance.

According study realized by E-commerce Europe, Romania occupied the 4th place in Europe, with the highest growth of online commerce, $24 \%$ increase of sales in 2015 and transactions of 1,49 million euro. In Romania, only 1,9 million buys online, around 11\% from population. At e-commerce B2C (Business to consumer), Great Britain is leader in Europe. In 2015, English spent online 157 billion euro, more than France - 64 billion euro, Germany - 59 billion euro and Russia - 20 billion euro. England, France and Germany totals $61,9 \%$ from e-commerce market of Europe.(see Table 1. Internet penetration :Top 10 Countries). In Romania, the most marketed B2C products (business to consumer) are in areas such as fashion, IT, media, entertainment and services - where the first place is the purchase of air tickets 30.4\% (380 million euros) followed by travel offers 39.5\% (101 million euros) and $45.7 \%$ insurance ( 52 million euros).

E-commerce Europe estimates that the online economy's gross domestic product ratio is $2.59 \%$ and may double by 2020 . In the coming years, the e-commerce market is expected to continue to grow reflecting sales of 510 billion in 2016, 598 billion euros in 2017 and 660 billion in 2018.

\section{Results and discussions}

The current trend in most of the banks is digitization, migration to the online environment. Digital banking offer services delivered over the World Wide Web, which presents different advantages for customers and banks. Customers enjoys the benefits of innovation, on the other point of view, the financial institutions enjoys better customer satisfaction, operational efficiency and a new potential business. Digital banking includes activities like: opening acurrent account, money deposit, applying for different banking products, loan, insurances, managing products.

For Bancassurance activity, this trend through digitalization may be a threat or an oportunity .

It might be a threat, because the reduction of number of branches creates risks for income fluctuations, as players will continue to rely on access to branches as their first channel of distribution and try to grow through their networks. But, can also be an opportunity, because a switch to online sales activities could lead to greater absorption of sales of insurance, while increasing digitization of transactions will create opportunities for offering insurance as a convenient addition to other products and services offered online.

Given the changing behavior of customers towards digitization, banks are increasingly adapting to create products sold through new distribution channels: internet banking and mobile banking.The financial institutions are faced to different challenges in front of the digital initiatives. The main challenge is to find the true value behind the digital implementations.

Now, Customers are much better informed, have greater negotiating power and higher expectations about the products and services they provide. The expectations of the customer are to achieve products and services "on one click distance", with all the conditions of the service very clearly and transparency. Already, digitization is starting to develop new relations between clients and financial institutions, to change business models.

According to the study realized by Ecommerce Europe, Europe have one of the biggest internet penetration rate from whole world, around 80.2\%, after North America with 
88\%. (see Fig.3.Internet World Penetration Rates by Geographic Regions)

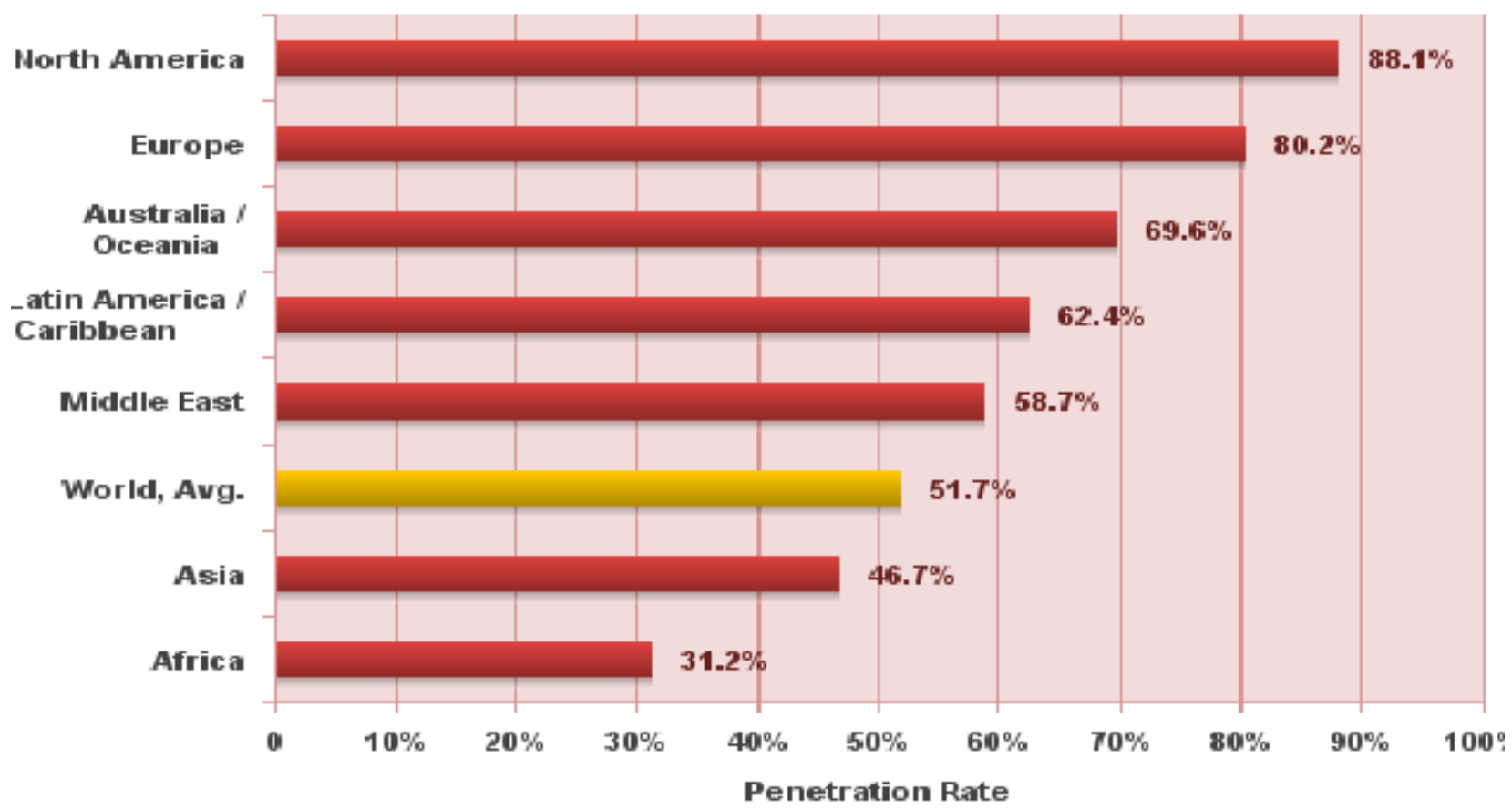

PICBE $\mid 608$

Figure 4.Internet World Penetration Rates by Geographic Regions-June30, 2017

Source: Internet World Stats-www.internetworldstats.com/stats.htm.

\begin{tabular}{|l|l|l|}
\hline Countries & $\begin{array}{l}\text { Share of population } \\
\text { using internet }\end{array}$ & $\begin{array}{l}\text { Online } \\
\text { population }\end{array}$ \\
\hline United Kingdom & $97.52 \%$ & $63 \mathrm{mn}$ \\
\hline South Korea & $95.21 \%$ & $48.3 \mathrm{mn}$ \\
\hline Japan & $92.69 \%$ & $116.83 \mathrm{mn}$ \\
\hline Australia & $92.44 \%$ & $22.8 \mathrm{mn}$ \\
\hline Germany & $91.76 \%$ & $74 \mathrm{mn}$ \\
\hline Canada & $91.41 \%$ & $33.5 \mathrm{mn}$ \\
\hline France & $86.55 \%$ & $56 \mathrm{mn}$ \\
\hline Spain & $82.32 \%$ & $38 \mathrm{mn}$ \\
\hline Russia & $79.44 \%$ & $114 \mathrm{mn}$ \\
\hline Israel & $79.17 \%$ & $6.6 \mathrm{mn}$ \\
\hline
\end{tabular}

Table 1. Internet penetration :Top 10 Countries

Source: International Telecommunication Union. http:/www.Itu.Int;Ecommerce Foundation,2017

Through E-Commerce Europe, the maximum potential of this market has not been reached. In present, $57 \%$ from consumers buy online. Europe's GDP is projected to reach 17.6 trillion euros in 2015, of which the EU member countries are close to 14.6 trillion euros.

According to this study, the potential of e-commerce is huge, so in a world that is run by profits, this may be an opportunity to develop new markets and distribution channels. In Romania, around 1.71 million persons (24.9\%) visited the web sites of banks, in the first half period of the year. (according www.gemius.com).Around 30\% of online bank users , 
have ages between 30 and 39 years old. Around 73\% have university studies, have a stabile job and lives in towns. Meanwhile, around 19.6\% never used online banking .

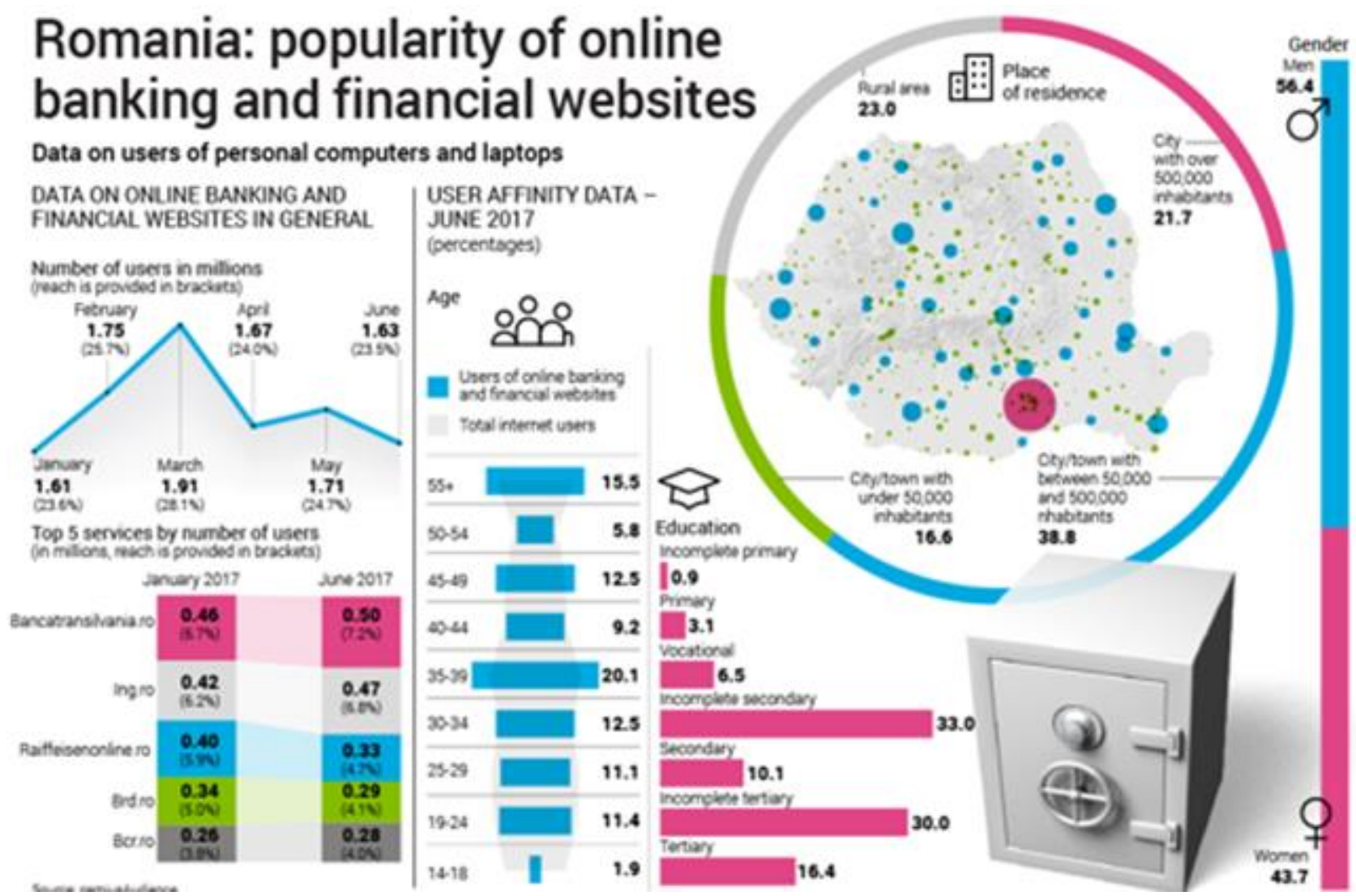

SBE $\mid 609$

Figure 5. Romania: popularity of online banking and financial websites

Source: https://www.gemius.com/all-reader-news/romaniaapproximately-one-in-five-internet-users-visit-financial-websites.html.

Also, social media platforms are a way to promote the brand cheaper than the average, to make you familiar to the young generation - Millenialls. The banking system in Romania is not ready yet, from the point of view of IT platforms, data confidentiality and customer confidence, to sell banking products on Facebook, Amazon, Ebay, but it is likely to grow in the future. One study shows that about $70 \%$ of young people use smartphones very often. Thus, traditional sales channels will expand their reach to the internet and mobile. The advantages for using social media platforms for insurers are various. First of all, it's a new way to connect with users, to build relationships with them, you have a quick response for announcements, launching of new products, increased availability of information, no geographic agents.

The main factor, that contributing to the sustainability of bancassurance in this full of changes period, might be the trust in financial institution. The customers need to be sure that benefits the same effective protection, as they achieve the product or service from the branch or online. In this aim, it came into force on 2016 and updates the 2002 Insurance Mediation Directive (IMD), which set out a framework for regulating EU insurance brokers, agents and other intermediaries. Member states have two years to transpose the IDD into national laws and regulations, ie before 23 February 2018 on which date it will repeal the 
IMD.

An integral part of regulatory changes impacting the financial services industry (e.g. PRIIPs, MiFID), the IDD will require all actors involved in the manufacturing and /or distribution of insurance products to review their business strategy, adapt their organisation, as well as rethink their future interactions.

Consumers should benefit from the same level of protection despite the differences between PICBE | 610 distribution channels. In order to guarantee that the same level of protection applies and that the consumer can benefit from comparable standards, in particular in the area of the disclosure of information, a level playing field between distributors is essential.

\section{Conclusions}

The focus of this study was to emphasize a better understanding of the bancassurance concept, the impact of the online environment on bancassurance activity, the trend of changing customer behavior towards digitization.

By digitizing, a new distribution channel will be created, so Bancassurance will have an increase in the sales area, giving customers the opportunity to access these products much faster and also to deepen the insurance conditions. Banks are in a continuous adaptation of products, according to customer needs and technological innovation. The most important way to make possible adapting to digitization of banks, is to invest in financial education of customers, in order to create a new business channel for banks and insurance companies.

The findings, highlight that there is a need for financial institutions to embrace digitalization; is a priority for all the branches of activity, whether we are dealing with ecommerce or financial institutions, the customer behavior is changing to online environment. This will allow banks and insurance companies to capitalize on this trend and embrace a new business.

As a result, the financial institutions must adapt by developing new innovative solutions. The adaptation and innovation is not only on their interest, but also for the customer.

\section{References}

Ahmadinia, H., Karim, M., \& Ofori, E. (2015). Primary analysis of information distribution at walkbase Company: Developing an information strategy. The Journal of Industrial Distribution \& Business, 6(4), 5-16.

Bergendahl, G. , (1995). 'The profitability of bancassurance for European banks'. Int. J. Bank Market. 13 (1), 17-28.

Capgemini (2017) /Online/. Retrieved from: https://www.capgemini.com/wpcontent/uploads/2017/07/Trends_in_Insurance_ Channels.pd

Chang, S. H., Chih, W. H., Liou, D. K., \& Yang, Y. T. (2016). The mediation of cognitive attitude for nline shopping. Information Technology \& People, 29(3), 618e646.

Competition Council (2009) /online/. Retrieved from: http://www.consiliulconcurentei.ro/uploads/docs/items/bucket10/id10007/consiliu l_concurentei-studiu privind sectorul asigurarilor de viata din romania.pdf 
Cronin, J. J., Brady, M. K., \& Hult, G. T. M. (2000). Assessing the effects of quality, value, and customer satisfaction on consumer behavioral intentions in service environments. Journal of Retailing, 76(2), 193e218.

Ecommerce Media (2017)/online/. Retrieved from: https://www.ecommercewiki.org Euro events (2017)/online/.Retrieved from: http://euro-events.co/bancassurance-3-0conference-digitalization-bancassurance-turning-opportunity-competitive-advantagepost-conference-report.

Farquhar,J.D , Meidan,A. (2010).Marketing financial services, Palgrave Macmillan, pg 230 240.

Friars,E., Gogel, R.(1987). The financial services handbook, A Wiley Interscience publication, pg 136-140.

Gemius Romania (2017). Romania: approximately one in five internet users visit financial websites/online/.Retrieved from: https://www.gemius.com/all-readernews/romania- approximately-one-in-five-internet-users-visit-financialwebsites.html

Gonulal, S.O ,Goulder, N.,Lester,R.(2012) -Bancassurance - A Valuable Tool for Developing Insurance in Emerging Markets, Policy Research Working Paper,The World Bank, Financial and Private sector Development,Non-Bank financial institutions, pg 1-20.

Hefferman,S(2004). Modern Banking, John Wiley\&Sons,ltd, pg 41-99.

Insurance Europe (2017) /online/. Retrieved from: https://www.insuranceeurope.eu/sites/default/files/attachments/WEB_Annual\%20 Report\%202016-2017.pdf.

Internet world stats (2017). Internet usage statistics/online/. Retrieved from: https://www.internetworldstats.com/stats.htm.

International Telecommunication Union. http:/www.Itu.Int; Ecommerce Foundation,2017

Negru, T. (2008). Insurance Economy , Methods, techniques, solutions, Economic Collection, Walters Kluwer.

Pearson, R. (2010). The Development on International Insurance, Routledge Taylor \&Francis Group London \&New York, pg 1-25.

Pantano, E., \& Timmermans, H. (2014). What is smart for retailing? Procedia Environmental Sciences, 22, 101-107.

PricewaterhouseCoopers (2016)/online/. Retrieved from: http://pwc.com.au/pdf/futureof-bancassurance.pdf.

Schmid, M.M. , Walter, I. , (2009). Do financial conglomerates create or destroy economic value? J. Financ. Intermed. 18 (2), 193-216.

Singhal, A.K. , Singh, R. , (2010). Bancassurance: leveraging on the synergy between the banking and insurance industry. IUP J. Risk Insur. 7 (1), 28-37.

Slijkerman, J.F. , Schoenmaker, D. , de Vries, C.G. ,2013. Systemic risk and diversification across European banks and insurers. J. Bank. Finance 37 (3), 773-785. 